\title{
Tindak Pidana Insider Trading Dalam Praktik Pasar Modal Indonesia
}

\author{
Ardian Junaedi \\ seduhmelagu@gmail.com \\ Universitas Airlangga
}

\begin{abstract}
Keywords: $\quad$ Abstract
Insider Trading; This article aims to analyze the qualifications of insider trading as criminal act according to Capital Market; $\quad$ Law No. 8 Year 1995 on Capital Market and to ascertain law enforcement against insider Law Enforcement. trading cases according to Law No. 8 Year 1995 on Capital Market. This article uses normative legal research methods with statutory conceptual, and a bit of case approach. The results of this article's research show that this insider trading as criminal act has been clearly qualified in the capital market law which, if necessary, has possibility to be combined with Article 323 paragraphs (1) and (2) of the Criminal Code regarding leakage secrets therefore it provides a legal basis for law enforcers including Financial Services Authority ("OJK") to take a decisive step in overcoming crime in capital market practices in Indonesia which will have an impact on investor's confidence to invest capital in Indonesia. Regarding to law enforcement on capital market crime has been considered frail as it is asserted from one oh the cases handled by OJK, namely PT. Bank Danamon Tbk, even though the existing legal instruments are sufficient to enforce strict law enforcement.
\end{abstract}

Kata Kunci: Insider Trading;

Pasar Modal; Penegakan Hukum.

\begin{abstract}
Abstrak
Artikel ini bertujuan untuk menganalisis kualifikasi Tindak Pidana Insider Trading (Perdagangan Orang Dalam) menurut Undang-Undang No. 8 Tahun 1995 tentang Pasar Modal dan untuk mengetahui penegakan hukum terhadap kasus Insider Trading Menurut Undang-Undang No. 8 Tahun 1995 tentang Pasar Modal. Artikel ini menggunakan metode penelitian hukum normatif dengan pendekatan perundang-undangan, konseptual, dan sedikit pendekatan kasus. Hasil penelitian artikel ini menunjukkan bahwa tindak pidana Insider Trading ini telah dikualifikasikan dengan jelas dalam Undang-Undang Pasar Modal yang jika perlu dapat pula dikombinasikan dengan Pasal 323 ayat (1) dan (2) KUHP mengenai tindak pidana pembocoran rahasia sehingga memberikan dasar hukum penindakan bagi para penegak hukum termasuk Otoritas Jasa Keuangan (OJK) untuk mengambil langkah tegas dalam mengatasi kejahatan dalam praktik pasar modal di Indonesia yang nantinya berdampak pada kepercayaan investor untuk menginvestasikan modalnya di Indonesia. Mengenai penegakan hukum kejahatan pasar modal selama ini masih dianggap lemah jika ditinjau dari salah satu kasus yang pernah ditangani oleh OJK yakni PT. Bank Danamon Tbk, padahal instrumen hukum yang ada sudah cukup memadai untuk dilakukan penegakan hukum yang tegas.
\end{abstract}

Copyright $@ 2020$ Universitas Airlangga

\section{Pendahuluan}

Pasar modal (capital market) merupakan pasar untuk berbagai instrumen keuangan jangka panjang yang bisa diperjualbelikan, baik surat utang (obligasi), 
ekuiti (saham), reksadana, instrumen derivatif maupun instrumen lainnya. Pasar modal juga menjadi sarana pendanaan bagi perusahaan maupun institusi lain (misalnya pemerintah), dan sebagai sarana bagi kegiatan berinvestasi. Dengan demikian, pasar modal memfasilitasi berbagai sarana dan prasarana kegiatan jualbeli dan kegiatan terkait lainnya. ${ }^{1}$

Pasar modal memiliki peran yang sangat strategis dalam pembangunan nasional sebagai salah satu sumber pembiayaan bagi dunia usaha dan wadah investasi bagi masyarakat. Kegiatan pasar modal yang begitu marak dan complicated membutuhkan suatu perangkat hukum untuk mengaturnya agar pasar tersebut teratur, wajar, dan adil bagi semua pihak. ${ }^{2}$ Dalam rangka mewujudkan kegiatan pasar modal yang teratur, wajar, dan efisien diperlukan adanya persyaratan yang wajib dipenuhi oleh pihak-pihak yang melakukan kegiatan di bidang pasar modal dan ketentuan mengenai sanksi administratif bagi pihak-pihak tertentu yang melakukan pelanggaran terhadap peraturan perundang-undangan di bidang pasar modal. ${ }^{3}$

Sejalan dengan hasil-hasil yang telah dicapai pembangunan nasional serta dalam rangka antisipasi atas globalisasi ekonomi, Undang-Undang No. 15 Tahun 1952 tentang Penetapan Undang-Undang Darurat tentang Bursa (Lembaran Negara Tahun 1951 No. 79) Sebagai Undang-Undang (Lembaran Negara Tahun 1952 No. 67) dipandang tidak sesuai lagi dengan kondisi kekinian. Berdasarkan pertimbangan tersebut diterbitkanlah Undang-Undang Nomor 8 Tahun 1995 tentang Pasar Modal (selanjutnya disingkat UUPM) yang bertujuan untuk menjamin kepastian hukum pihak-pihak yang melakukan kegiatan di pasar modal.

Perkembangan hukum berkaitan erat dengan perkembangan yang terjadi di dalam masyarakat, hal tersebut sejalan dengan adagium “Ubi Societas ibi ius" yang berarti dimana ada masyarakat disitu ada hukum. Konsekuensi kegiatan yang pesat di bidang ekonomi menyebabkan peraturan yang ada di bidang perekonomian

\footnotetext{
${ }^{1}$ Martalena, Pengantar Pasar Modal (ANDI 2011).[2].

${ }^{2}$ Kadek Endra Bayu Sudiartha dan Made Subawa, 'Perlindungan Hukum Terhadap Investor Untuk Menghindari Kerugian Akibat Praktek Manipulasi Pasar Dalam Pasar Modal' (2013) 1 Jurnal Kertha Semaya.[2].

${ }^{3}$ Mohammad Solehuddin Attijani, 'Penyelenggara Dana Perlindungan Pemodal Bagi Investor Dalam Transaksi Saham Pada Pasar Modal' (2019) 2 Media Iuris. [158].
} 
dianggap tidak lagi dapat mengikuti dan mengakomodir kebutuhan hukum di bidang ini, sehingga dibutuhkan aturan yang baru di bidang hukum ekonomi.

Dalam praktiknya, kegiatan yang dilakukan di pasar modal melibatkan berbagai pihak yang secara umum bertujuan untuk mencari keuntungan. Dalam konsep yang demikian bukan berarti para pihak bebas memanfaatkan berbagai keadaan demi tujuannya di pasar modal termasuk melakukan kecurangan atau pelanggaran. Pelanggaran terhadap aturan main dalam transaksi efek sering disebabkan karena lemahnya sistem pengawasan yang dilakukan oleh pihak pengelola bursa maupun pengawas bursa, sehingga apabila terjadi pelanggaran transaksi efek baik karena manipulasi, informasi yang menyesatkan maupun Insider Trading (Perdagangan Orang Dalam) sulit terdeteksi secara dini. ${ }^{4}$

Pasar modal memiliki prinsip keterbukaan sebagai jiwa dari pasar modal tersebut yang bertujuan untuk memelihara kepercayaan publik terhadap pasar, menciptakan mekanisme pasar yang efisien, dan juga untuk memberi perlindungan terhadap investor. ${ }^{5}$ Salah satu cara untuk mewujudkan prinsip keterbukaan informasi dalam pasar modal adalah perusahaan publik yang dibantu profesi penunjang harus menyediakan prospektus yang benar yakni informasi tertulis sehubungan dengan penawaran umum. ${ }^{6}$ Sebenarnya yang diperdagangkan di pasar modal adalah kepercayaan. Kepercayaan masyarakat pada nilai saham, benarnya laporan perusahaan, Prospek keuntungan di masa mendatang, Kebijaksanaan pemerintah yang mendukung pasar modal sampai kepada jaminan bahwa hukum akan dipatuhi para pihak. ${ }^{7}$ Pelanggaran terhadap prinsip keterbukaan informasi ini dapat mengakibatkan penyimpangan pada pasar modal salah satunya praktek Insider Trading (Perdagangan Orang Dalam).

\footnotetext{
4 Munir Fuady, Pasar Modal Modern (Tinjauan Hukum) (Citra Aditya Bakti 1996).[4].

5 Ade Hendra Jaya dan I Nyoman Gatrawan, 'Akibat Hukum Adanya Misleading Information Pada Prospektus Ditinjau Dari Hukum Pasar Modal’ (2013) 1 Jurnal Kertha Semaya.[2].

6 Ni Putu Purwanti, Inocencio Arya Wahyudi Karditha, I Ketut Westra, 'Tanggung Jawab Akuntan Publik Dalam Pembuatan Prospektus Pada Kegiatan Di Pasar Modal' (2013) 1 Jurnal Kertha Semaya.[1].

7 Pande Putu Mega Rahma Wulandari dan Gede Made Swardhana, 'Tanggung Jawab Terhadap pelanggaran Prinsip Keterbukaan Dalam Pasar Modal Terkait Perdagangan Saham' (2017) 5 Jurnal Kertha Semaya.[3].
} 
Insider Trading menurut Sofyan A. Djalil merupakan istilah teknis yang hanya dikenal dalam pasar modal. Istilah ini mengacu pada praktik dimana orang dalam perusahaan (corporate insiders) melakukan transaksi sekuritas (trading) dengan menggunakan informasi ekslusif yang mereka miliki (inside nonpublic information) artinya segala informasi yang penting dan dapat mempengaruhi harga securities dan informasi tersebut belum diumumkan kepada khalayak ramai. ${ }^{8}$ Insider trading merupakan salah satu kejahatan yang tercanggih di dunia yang umumnya dilakukan dengan modus yang sangat rumit dan sangat sulit dilacak. Para pelaku Insider Trading pada umumnya juga merupakan orang-orang terpelajar atau berpendidikan. Padahal di dalam Pasal 104 UUPM disebutkan bahwa praktek Insider Trading (Perdagangan Orang Dalam) termasuk dalam tindak kejahatan pidana.

Praktek Insider Trading berpengaruh besar terhadap perkembangan pasar modal Indonesia secara keseluruhan, oleh karena itu membutuhkan perhatian khusus dari pemerintah karena Insider Trading ini membawa pengaruh buruk terhadap iklim investasi yang dapat merugikan investor yang menanamkan modalnya di Indonesia. Pada kondisi tersebut hukum di Indonesia seharusnya hadir dan memberikan perlindungan yang tegas terhadap para investor terkait dengan praktek Insider Trading ini.

Berdasarkan uraian tersebut diatas, artikel ini ingin mengetahui dan mengkaji lebih lanjut mengenai tindak pidana kejahatan Insider Trading (Perdagangan Orang Dalam) di dalam pasar modal.

\section{Metode Penelitian}

Artikel ini menggunakan tipe penelitian hukum normatif atau doktrinal, yang menurut Peter Mahmud Marzuki adalah suatu proses untuk menemukan suatu aturan hukum, prinsip-prinsip hukum, maupun doktrin-doktrin hukum guna menjawab isu hukum yang dihadapi. ${ }^{9}$

${ }^{8}$ Ida Ayu Nyoman Mahayani Dewi dan I Wayan Suarbha, 'Penanggulangan Perdagangan Orang Dalam (Insider Trading) Di Bidang Pasar Modal Ditinjau Dari Perspektif Hukum Pidana' (2014) 3 Jurnal Kertha Wicara [2].

9 Peter Mahmud Marzuki, Penelitian Hukum (Pranada Media Group 2011).[ 35]. 
Pendekatan yang digunakan dalam penelitian ini adalah pendekatan Perundang-undangan (Statute Approach), pendekatan konseptual (Conceptual Approach), dan sedikit pendekatan kasus (Case Approach). Pendekatan Perundanganundangan adalah pendekatan yang dilakukan dengan menelaah semua UndangUndang dan regulasi yang bersangkut paut dengan isu hukum yang ditangani. Pendekatan konseptual (conceptual approach) merupakan pendekatan yang dilakukan dengan mencari teori serta doktrin yang telah ada untuk dijadikan suatu acuan agar dapat memahami suatu pandangan-pandangan dan doktrin-doktrin dalam membangun suatu argumentasi hukum dalam memecahkan isu yang sedang dihadapi. ${ }^{10}$ Pendekatan kasus adalah pendekatan yang dilakukan dengan cara melakukan telaah terhadap kasus-kasus yang berkaitan dengan isu yang dihadapi.

Adapun bahan hukum yang digunakan dalam artikel ini, yaitu Bahan Hukum Primer yang terdiri dari peraturan perundang-undangan yang terkait dengan pasar modal dan kasus transaksi Saham pada PT Bank Danamon Indonesia Tbk. Bahan Hukum Sekunder terdiri dari buku, jurnal, skripsi, artikel, keterangan ilmiah, dan bacaan lain yang erat kaitannya dengan masalah yang diteliti. Kemudian artikel ini akan diuraikan dengan menelaah, menjelaskan, memaparkan, dan memberikan gambaran secara jelas dan konkret terhadap objek yang dibahas secara deduktif untuk selanjutnya menganalisis permasalahan hukum yang akan diteliti yang kemudian dikaitkan dengan peraturan perundang-undangan dan ketentuan hukum yang berlaku. ${ }^{11}$

\section{Kualifikasi Tindak Pidana Insider Trading berdasarkan Undang-Undang Nomor 8 Tahun 1995 Tentang Pasar Modal}

Tindak Pidana Insider Trading dalam Undang-Undang Nomor 8 tahun 1995 tentang Pasar Modal terdapat 3 (tiga) Pasal yang terkait, yaitu Pasal 95, Pasal 96 dan Pasal 97. Adapun penjelasan dari ketiga Pasal tersebut adalah sebagai berikut:

${ }^{10}$ Muh Arief Syahroni Addinul Haq Yaqub, Dhanitya Putra Prawira, 'The Antinomy of Fictive State Administrative Decision in Indonesian Statute' (2019) 6 Jurnal Jurisprudentie.[6].

${ }^{11}$ Putu Wahyu Ning Egarini dan I Made Sarjana, 'Problematika Memorandum of Understanding' (2020) 8 Jurnal Kertha Semaya.[6]. 


\section{a. Pasal 95 UUPM}

"Orang dalam dari Emiten atau Perusahaan Publik yang mempunyai informasi orang dalam dilarang melakukan pembelian atau penjualan atas Efek: a. Emiten atau Perusahaan Publik dimaksud; atau b. Perusahaan lain yang melakukan transaksi dengan Emiten atau Perusahaan Publik yang bersangkutan"

Adapun unsur-unsur yang terdapat dalam Pasal 95 UUPM adalah sebagai berikut:

1) Orang dalam dari Emiten atau Perusahaan Publik disini berarti subyek hukum yaitu setiap orang dalam dari emiten atau pribadi dapat bertanggungjawab dan cakap hukum sesuai dengan peraturan perundang-undangan serta badan hukum.

2) Yang mempunyai informasi orang dalam, yang dimaksud dengan yang mempunyai informasi orang dalam adalah komisaris, direktur, atau pegawai Emiten, pemegang saham utama Emiten yang karena kedudukan atau fungsinya terdapat kemungkinan memperoleh segala informasi yang berkaitan dengan perusahaan.

3) Dilarang melakukan pembelian atau penjualan atas efek, artinya tidak diperbolehkannya semua bentuk transaksi yang terjadi antara Emiten atau Perusahaan Publik dan perusahaan lain.

4) Huruf a. Emiten atau Perusahaan Publik yang dimaksud adalah larangan bagi orang dalam untuk melakukan pembelian atau penjualan atas Efek Emiten atau Perusahaan Publik yang bersangkutan didasarkan atas pertimbanganbahwakedudukanorangdalam seharusnyamendahulukan kepentingan Emiten, Perusahaan Publik, atau pemegang saham secara keseluruhan termasuk di dalamnya untuk tidak menggunakan informasi orang dalam untuk kepentingan diri sendiri atau Pihak lain.

5) Huruf b. Perusahaan lain yang melakukan transaksi dengan Emiten atau Perusahaan Publik yang bersangkutan adalah di samping larangan yang tercantum dalam huruf a, orang dalam dari suatu Emiten atau Perusahaan Publik yang melakukan transaksi dengan perusahaan lain juga dikenakan larangan untuk melakukan transaksi atas Efek dari perusahaan lain tersebut, meskipun yang bersangkutan bukan orang dalam dari perusahaan lain tersebut. Hal ini karena informasi mengenai perusahaan lain tersebut lazimnya diperoleh karena kedudukannya pada Emiten atau Perusahaan Publik yang melakukan transaksi dengan perusahaan lain tersebut.

\section{b. Pasal 96 UUPM}

“Orang dalam sebagaimana dimaksud dalam Pasal 95 dilarang: a. mempengaruhi pihak lain untuk melakukan pembelian atau penjualan atas Efek dimaksud; atau b. memberi informasi orang dalam kepada Pihak mana pun yang patut diduganya dapat menggunakan informasi dimaksud untuk 
melakukan pembelian atau penjualan atas Efek".

Adapun unsur-unsur yang terdapat dalam Pasal 96 UUPM adalah sebagai berikut:

1) Orang dalam sebagaimana dimaksud dalam Pasal 95 dilarang mempengaruhi pihak lain untuk melakukan pembelian dan atau penjualan atas Efek dari Emiten atau Perusahaan Publik yang bersangkutan dimaksudkan bahwa walaupun orang dalam dimaksud tidak memberikan informasi yang bersifat ekslusif kepada pihak lain, namun terdapat pula larangan untuk tidak mempengaruhi keputusan pihak lain karena hal ini dapat mendorong pihak lain untuk melakukan pembelian atau penjualan Efek berdasarkan informasi orang dalam.

2) Orang dalam dilarang memberikan informasi orang dalam kepada Pihak lain yang diduga akan menggunakan informasi tersebut untuk melakukan pembelian dan atau penjualan Efek. Dengan demikian, orang dalam mempunyai kewajiban untuk berhati-hati dalam menyebarkan informasi agar informasi tersebut tidak disalahgunakan oleh pihak yang menerima informasi tersebut untuk melakukan pembelian atau penjualan atas Efek.

c. Pasal 97 UUPM

1) “Ayat (1) Setiap pihak yang berusaha untuk memperoleh informasi orang dalam dari orang dalam secara melawan hukum dan kemudian memperolehnya dikenakan larangan yang sama dengan larangan yang berlaku bagi orang dalam sebagaimana dimaksud dalam Pasal 95 dan Pasal 96. Artinya, mereka dilarang untuk melakukan transaksi atas Efek yang bersangkutan, serta dilarang mempengaruhi pihak lain untuk melakukan pembelian dan atau penjualan atas Efek tersebut atau memberikan informasi orang dalam tersebut kepada pihak lain yang patut diduga akan menggunakan informasi tersebut untuk melakukan pembelian dan penjualan Efek. Sebagai contoh perbuatan melawan hukum, antara lain: a. berusaha memperoleh informasi orang dalam dengan cara mencuri; 
b. berusaha memperoleh informasi orang dalam dengan cara membujuk orang dalam; dan c. berusaha memperoleh informasi orang dalam dengan cara kekerasan atau ancaman.

2) Ayat (2) disebutkan bahwa “Setiap Pihak yang berusaha untuk memperoleh informasi orang dalam dan kemudian memperolehnya tanpa melawan hukum tidak dikenakan larangan yang berlaku bagi orang dalam sebagaimana dimaksud dalam Pasal 95 dan Pasal 96, sepanjang informasi tersebut disediakan oleh Emiten atau Perusahaan Publik tanpa pembatasan." Artinya, Setiap orang yang memperoleh informasi secara tanpa melawan hukum tidak dikenakan sanksi. Sebagai contoh, apabila seseorang yang bukan orang dalam meminta informasi dari Emiten atau Perusahaan Publik dan kemudian memperolehnya dengan mudah tanpa pembatasan, orang tersebut tidak dikenakan larangan yang berlaku bagi orang dalam. Namun, apabila pemberian informasi orang dalam disertai dengan persyaratan untuk merahasiakannya atau persyaratan lain yang bersifat pembatasan, terhadap pihak yang memperoleh informasi orang dalam berlaku larangan sebagaimana dimaksud dalam Pasal 95 dan Pasal 96.

\section{d. Pasal 98 UUPM}

"Perusahaan Efek yang memiliki informasi orang dalam mengenai Emiten atau Perusahaan Publik dilarang melakukan transaksi Efek Emiten atau Perusahaan Publik tersebut, kecuali apabila: a. transaksi tersebut dilakukan bukan atas tanggungannya sendiri, tetapi atas perintah nasabahnya; dan b. Perusahaan Efek tersebut tidak memberikan rekomendasi kepada nasabahnya mengenai Efek yang bersangkutan." Ketentuan Pasal ini memberi kemungkinan Perusahaan Efek untuk melakukan transaksi Efek semata-mata untuk kepentingan nasabahnya karena salah satu kegiatan Perusahaan Efek adalah sebagai Perantara Pedagang Efek yang wajib melayani nasabahnya dengan sebaik-baiknya. Dalam melaksanakan transaksi Efek dimaksud, Perusahaan Efek tidak memberikan rekomendasi apa pun kepada nasabahnya tersebut. Apabila larangan dalam Pasal ini dilanggar, Perusahaan Efek melanggar ketentuan orang dalam sebagaimana dimaksud dalam Pasal 95 dan Pasal 96.

Unsur-unsur yang tercantum dalam ketentuan-ketentuan diatas mengenai tindak pidana perdagangan orang (insider trading) secara garis besar dapat pula 
dikombinasikan dengan ketentuan yang tercantum dalam Pasal 323 ayat (1) dan ayat (2) KUHP mengenai tindak pidana pembocoran rahasia/perbuatan membuka rahasia, sehingga penegakan hukum terhadap kejahatan pasar modal salah satunya insider trading tidak hanya dikenakan sanksi administrasi saja tapi juga diperlukan pemberian sanksi pidana sebagai ultimum remedium untuk memaksakan ketaatan. Penegakan hukum yang konsisten terhadap para pihak yang melakukan pelanggaran dapat menjadi pendorong bagi para pihak yang lain untuk selalu mematuhi ketentuan dan menerapkan prinsip kehati-hatian dalam melakukan usahanya atau dalam bertransaksi. ${ }^{12}$

\section{Penegakan Hukum Terhadap Kasus Insider Trading Menurut Undang-Undang No. 8 Tahun 1995 tentang Pasar Modal}

Penegakan hukum merupakan suatu usaha untuk mewujudkan ide-ide tentang kepastian hukum, kemanfaatan sosial, dan keadilan menjadi kenyataan. ${ }^{13}$ Penegakan hukum insider trading memerlukan landasan hukum yang jelas agar memudahkan para penegak hukum dalam menerapkan peraturan perundangundangan. Dalam UUPM tepatnya pada Pasal 95 sampai dengan Pasal 99 telah memuat ketentuan bahwa insider trading (Perdagangan Orang Dalam) termasuk dalam salah satu jenis kejahatan pasar modal yang artinya perbuatan tersebut dapat dikenai sanksi baik itu sanksi administrasi maupun sanksi pidana.

Ketentuan mengenai sanksi pun salah satunya berupa sanksi pidana telah diatur secara khusus dalam Pasal 104 UUPM bahwa "Setiap pihak yang melanggar ketentuan sebagaimana dimaksud dalam Pasal 90, Pasal 91, Pasal 92, Pasal 93, Pasal 95, Pasal 96, Pasal 97 ayat (1), dan Pasal 98 diancam dengan pidana penjara paling lama 10 (sepuluh) tahun dan denda paling banyak Rp. 15.000.000.000,00 (limabelas milyar rupiah)." Penanggulangan kejahatan dengan menggunakan

12 I Kadek Andi Wijaya dan Ni Nyoman Sukeni, 'Tanggung Jawab Emiten Dan Profesi Penunjang Atas Adanya Prospektus Yang Tidak Benar Dalam Kegiatan Di Pasar Modal’ (2013) 1 Jurnal Kertha Semaya.[4].

13 Moh Heriyanto, Wahyu Hidayatullah dan Mulyadi, 'Konsep Kriminalisasi Penegakan Hukum Terhadap Pembeli Aktif Ilegal Obat Keras Daftar "G" Jenis Trihexyphenidil' (2020) 3 Media Iuris.[67]. 
hukum pidana merupakan bagian dari kebijakan kriminal yang dianggap sebagai upaya hukum yang paling rasional. ${ }^{14}$

Salah satu hal menarik yang dapat ditelaah terkait dengan insider trading dapat dilihat pada kasus transaksi saham PT Bank Danamon Indonesia Tbk. ${ }^{15}$ Namun, terlebih dahulu perlu diketahui secara singkat kasus posisinya.

“Rajiv Louis melakukan aksi insider trading pada 30 Maret 2012, kala dirinya menjabat sebagai kepala DBS Indonesia. Rajiv Louis telah memanfaatkan informasi rencana pembelian saham Bank Danamon oleh DBS Group Holdings Ltd, transaksi dilakukan setelah Louis memperoleh informasi nonpublik dari proposal akuisisi Bank Danamon oleh DBS Group Holding Ltd. Dengan membeli saham BDMN lewat rekening istrinya di singapura. Rajiv Louis memborong 1 juta lembar saham PT Bank Danamon Tbk (BDMN) pada Maret 2012.

Rajiv Louis mendapat untung besar, berkat harga saham Danamon yang melambung tinggi setelah pengumuman tersebut. Pengumuman resmi DBS atas rencana akuisisi saham BDMN pun baru terlaksana pada April 2012, atau sebulan setelah Rajiv Louis melancarkan aksinya. Akibat tindakan curang itu, Rajiv Louis memperoleh keuntungan sebesar US\$ 173.956 (2,2 miliar rupiah).

Monetary Authority of Singapore (MAS) mengganjar Rajiv Louis dengan hukuman denda penalti sebesar US\$ 312.965 (4,3 miliar rupiah). Rajiv Louis sendiri bersedia membayar denda yang diputuskan otoritas Singapura tanpa melalui proses persidangan dan putusan pengadilan".

Monetary Authority of Singapore (MAS) mengambil langkah tegas dengan menjatuhkan sanksi denda terhadap kasus insider trading yang dilakukan oleh Rajiv Louis, namun di sisi lain Otoritas Jasa Keuangan (OJK) malah terkesan lebih pasif dalam menegakkan aturan terkait kasus insider trading meskipun dalam UUPM insider trading (Perdagangan Orang Dalam) termasuk dalam salah satu jenis kejahatan pasar modal yang tertuang dalam Pasal 95 sampai dengan Pasal 99. Dalam berbagai ketentuan dinyatakan bahwa OJK sebagai lembaga yang berfungsi untuk menyelenggarakan pengaturan dan pengawasan di dalam sektor jasa keuangan termasuk sektor pasar modal mempunyai tujuan sebagaimana

${ }^{14}$ Ida Ayu Nyoman Mahayani Dewi dan I Wayan Suarbha., Op.Cit.[4].

15 CNN indonesia, 'Kasus Insider Trading Saham Danamon BEI Temui UBS Indonesia' <https:/ / www.cnnindonesia.com/ekonomi/20151016132758-92-85309/kasus-insider-tradingsaham-danamon-bei-temui-ubs-indonesia> accessed 14 June 2020. 
tercantum di dalam Pasal 4 Undang-Undang Nomor 21 Tahun 2011 tentang Otoritas Jasa Keuangan yang salah satu tujuannya adalah untuk melindungi kepentingan konsumen dan masyarakat. ${ }^{16}$ berhak untuk melakukan proses pemeriksaan dan penyidikan terhadap para pihak yang melakukan jenis kejahatan pasar modal. Dengan kata lain, sebagai lembaga pengawas pasar modal OJK memiliki tanggung jawab untuk menegakkan hukum bila terjadi pelanggaran perundang-undangan pasar modal atau ketentuan di bidang pasar modal lainnya.

Dari uraian yang ada dapat dinyatakan bahwa, insider trading dapat diartikan sebagai suatu perdagangan efek yang dilakukan oleh orang dalam perusahaan, dimana perdagangan tersebut didasarkan atau dimotivasi karena adanya suatu informasi orang dalam yang penting dan belum ter-publish untuk publik, yang dari perdagangan tersebut, orang dalam tersebut mengharapkan akan mendapatkan keuntungan jalan pintas secara pribadi, langsung atau tidak langsung. Dari pengertian tersebut, perdagangan orang dalam (insider trading) mengandung beberapa unsur, yaitu:
a. Adanya transaksi perdagangan efek;
b. Dilakukan oleh orang-orang dalam perusahaan (insider);
c. Adanya informasi orang dalam;
d. Informasi tersebut belum ter-publish untuk publik;
e. Transaksi perdagangan tersebut dimotivasi oleh informasi tersebut;
f. Tujuan untuk mendapat keuntungan.

Dari Unsur-unsur diatas maka dapat kita urutkan satu persatu sesuai kasus posisi yang telah diuraikan sebelumnya.

Pertama, mengenai adanya transaksi perdagangan efek, Unsur ini telah terpenuhi dengan terbuktinya bahwa Rajiv Louis telah memborong 1 juta lembar saham PT Bank Danamon Tbk (BDMN) pada Maret 2012. Dimana sebelum adanya keterbukaan informasi dari PT Bank Danamon Tbk untuk diakuisisi sahamnya oleh DBS GroupHoldings Ltd.

${ }^{16}$ Lana Almira Luthfiana Istiqlal dan Dian Purnama Anugerah, 'Perlindungan Hukum Bagi Konsumen Pengguna Kartu Debit Terkait Pembebanan Biaya Tambahan Pada Mesin EDC (Electronic Data Captured)' (2020) 3 Media Iuris. [46]. 
Selanjutnya mengenai dilakukan oleh orang dalam (insider), pihak yang termasuk sebagai orang dalam diatur dalam penjelasan Pasal 95 UUPM salah satunya adalah “Orang perseorangan yang karena kedudukan atau profesinya atau karena hubungan usahanya dengan Emiten atau Perusahaan Publik memungkinkan orang tersebut memperoleh informasi orang dalam" Rajiv Louis yang telah memperoleh informasi non-publik dari proposal akuisisi Bank Danamon oleh DBS Group Holding Ltd telah dapat dikategorikan sebagai orang dalam (insider). Unsur Adanya informasi orang dalam pada kasus ini sudah sangat jelas bahwa dengan adanya informasi yang diperoleh oleh Rajiv Louis mengenai informasi non-publik dari proposal akuisisi Bank Danamon oleh DBS Group Holding Ltd merupakan suatu informasi dari orang dalam.

Informasi tersebut belum ter-publish untuk publik, yang dimaksud disini adalah informasi mengenai akuisisi Bank Danamon oleh DBS Group Holding Ltd. yang diumumkan pada bulan april 2012 Sebelumnya masih bersifat rahasia dan belum diberitahukan kepada umum ketika Rajiv Louis melakukan transaksi sahamnya pada maret 2012.

Transaksi perdagangan tersebut dimotivasi oleh informasi tersebut, berdasarkan informasi yang didapat oleh Rajiv Louis mengenai akuisisi Bank Danamon oleh DBS Group Holding Ltd membuatnya untuk membuat akun menggunakan rekening istrinya melalui salah satu broker yang terdapat di singapura untuk melakukan transaksi pembelian saham BDMN saat itu.

Tujuan mendapat keuntungan, unsur ini juga telah terbukti dengan adanya keuntungan yang telah diperoleh Rajiv Louis sebesar US\$ 173.956 (2,2 miliar rupiah). Setelah melakukan perdagangan menggunakan informasi yang telah ia terima sebelumnya. Transaksi yang dilakukan oleh Rajiv Louis telah memenuhi semua syarat terjadinya insider trading maka kepada orang tersebut dapat diduga telah melakukan praktik insider trading kecuali jika pengadilan memutuskan sebaliknya. Berdasarkan hal itu seharusnya OJK dapat melakukan penyelidikan dan penyidikan lebih lanjut untuk menilai apakah sesungguhnya telah terjadi suatu insider trading dalam aktivitas transaksinya. Penyidikan ini merupakan langkah 
awal dalam melakukan penuntutan atas tindak pidana yang telah dilakukan oleh pelaku, dan jika memang setelah dilimpahkan kepada pengadilan, pelaku terbukti secara sah bersalah melakukan praktik insider trading maka pelaku dapat dikenakan pidana berdasarkan pasal 104 UUPM yaitu maksimal 10 (sepuluh) tahun penjara dan denda maksimal RP. 15.000.000.000,00. (lima belas miliar rupiah).

Dalam Kasus Insider Trading PT Bank Danamon Indonesia Tbk telah terjadi pelanggaran prinsip Disclose or a stain theory yaitu suatu teori yang melarang setiap orang yang memiliki informasi non publik maupun memiliki hubungan dengan emiten untuk terlibat dalam perdagangan efek dari emiten tersebut. Jika pihak yang memiliki akses terhadap informasi non publik, maupun pihak yang memiliki hubungan dengan pemilik akses terhadap informasi non publik tersebut ingin terlibat, maka informasi tersebut harus diungkapkan terlebih dulu kepada publik.

Dalam kasus ini juga telah terjadi pelanggaran atas prinsip Misapproapriation theory yaitu teori yang menyatakan bahwa transaksi yang dilakukan oleh pihak non insider yang dilakukan berdasarkan informasi yang tersedia bagi publik dianggap sebagai transaksi insider trading. Setiap "outsider" yang memperoleh informasi non publik dianggap diberikan kepercayaan untuk merahasiakan informasi tersebut dan tidak bertindak berdasarkan informasi non publik yang diterima.

Informasi rencana pembelian saham Bank Danamon oleh DBS Group Holdings Ltd dalam peristiwa insider trading PT. Bank Danamon Indonesia Tbk dikategorikan sebagai fakta materiil dalam Peraturan Nomor X.K.1. Dalam Pasal 86 ayat (2) UUPM yang menyatakan bahwa perusahaan publik menyampaikan laporan kepada Bapepam dan mengumumkan kepada masyarakat tentang peristiwa materiil yang dapat mempengaruhi harga efek selambat-lambatnya pada akhir hari kerja ke-2 (kedua) setelah terjadinya peristiwa tersebut. Pada kenyataannya PT. Bank Danamon Indonesia Tbk terlambat melaporkan fakta atas rencana pembelian saham Bank Danamon oleh DBS Group Holdings Ltd yang dilakukan oleh PT Bank Danamon Indonesia Tbk. Dengan demikian, PT. Bank Danamon Indonesia Tbk. melanggar pasal 86 ayat (2) UUPM jo. Peraturan Nomor X.K.1. 
Ketentuan tersebut menunjukkan adanya keselarasan dalam unsur tindak pidana insider trading dengan apa yang telah dilakukan oleh Rajiv Louis, maka dari itu MAS secara tegas langsung menjatuhi sanksi denda terhadap Rajiv Louis sehingga menunjukkan suatu ketegasan dalam menegakkan hukum dari badan pengawas pasar modal di Singapura tersebut, dan langkah tersebut juga berarti ikut mendukung perkembangan pasar modal di Singapura untuk lebih terpercaya dari para pelaku pasar terhadap pasar modal yang menjadi sarana investasinya.

Disisi lain peran dari OJK sebagai penanggungjawab dari badan pengawas Pasar Modal di Indonesia justru melepaskan kasus tersebut. Hal tersebut merupakan suatu keganjalan karena dalam hal melakukan pemeriksaan dan penyidikan atas terjadinya pelanggaran UUPM OJK memiliki kewenangan penegakan hukum sebagai Penyidik Pegawai Negeri Sipil. Pendelegasian kekuasaan Bapepam-LK kepada OJK juga diperluas, yaitu mempunyai kekuasaan untuk mengenakan sanksi administrasi yang jumlahnya cukup banyak dalam pelaksanaan kekuasaannya. Termasuk dalam kekuasaan pengenaan sanksi adalah untuk mengenakan denda, pembatasan dan pembekuan kegiatan usaha, pencabutan izin usaha serta pembatalan persetujuan pendaftaran (Pasal 102 UUPM). OJK mempunyai kewenangan seperti layaknya polisi dalam melakukan pemeriksaan dan penyidikan, hal tersebut ada pada Pasal 100 dan 101 UUPM. Seharusnya dengan kewenangan yang sangat besar tersebut OJK dapat lebih kuat dalam membongkar kasus-kasus yang terindikasi insider trading maupun kejahatan di dalam pasar modal lainnya.

Larangan perdagangan oleh orang dalam ini mulai diperkenalkan dengan diberlakukannya Keputusan Menteri Keuangan nomor 1548/KMK/013/1990 tentang Pasar Modal sebagaimana diubah dengan Keputusan Menteri Keuangan Nomor 284/KMK.010/1995, yang kemudian diperkuat dengan diberlakukannya UUPM. Ketentuan mengenai perdagangan orang dalam ini ditentukan dalam Pasal 95-98 UUPM. Ketentuan selanjutnya dari UUPM ini (Pasal 96-98) memperluas jangkauan dari Pasal 95 baik terhadap orang dalam yang mendorong/ mempengaruhi orang lain atau memberikan informasi orang dalam kepada pihak 
lain (Pasal 96), atau "orang luar" yang berusaha untuk memperoleh informasi orang dalam tersebut secara melawan hukum (Pasal 97) serta juga terhadap perusahaa efek/anggota bursa (Pasal 98).

Menurut penulis Misapproapriation theory juga merupakan suatu terobosan yang sangat efektif terhadap peraturan mengenai UUPM yang ada di Indonesia sekarang yang sudah sangat tertinggal. Pada pengaturan pasar modal Indonesia, praktek insider trading banyak dilandasi oleh adanya hubungan fiduciary duty antara pelaku dengan perusahaan tempat ia bekerja dan mendapatkan akses kepada informasi orang dalam. Akan tetapi dalam beberapa pasal dalam UUPM, dapat diperhatikan bahwa sesungguhnya pembuat UU tersebut mempunyai maksud untuk mencakup pihak selain "orang dalam" sebagaimana dijabarkan pada Pasal 95 UUPM. Pihak tersebut adalah pihak yang bukan merupakan orang dalam yang mendapatkan informasi orang dalam dari insider atau yang biasa disebut dengan tippee.

Kelemahan pada pengaturan mengenai insider trading atau pihak yang dilarang untuk melakukan transaksi efek dalam UUPM di Indonesia adalah tidak diaturnya mengenai tippee yang mendapat informasi orang dalam secara pasif (tidak melakukan usaha). Bilamana dikaitkan dengan misappropriation theory, maka sebenarnya teori tersebut dapat menjangkau semua pihak, baik itu insider sebagaimana dimaksud pada Pasal 95 UUPM, maupun pihak ketiga seperti pada Pasal 97 ayat (1) dan (2) UUPM. Oleh karena itu, dengan merujuk unsur-unsur misappropriation theory sebagaimana diuraikan di atas, maka unsur apakah adanya usaha atau tidak dari tippee untuk mendapatkan informasi orang dalam tidak diperhitungkan lagi. Faktor esensial yang menetukan apakah ia dapat digolongkan sebagai pelaku insider trading atau tidak adalah apakah kemudian ia melakukan transaksi efek dengan informasi tersebut dan mendapat keuntungan dari transaksi tersebut. Dengan demikian, inti dari teori tersebut adalah adanya penyalahgunaan informasi, yakni informasi orang dalam (yang masih bersifat rahasia) digunakan untuk kepentingan pribadi atau beberapa pihak tertentu yang mendapatkan informasi tersebut. Informasi materiil tersebut sebenarnya adalah bersifat wajib untuk dibuka kepada masyarakat 
sebagaimana prinsip keterbukaan, sehingga dengan informasi tersebut para pemegang saham atau calon investor dapat mempertimbangakan apakah akan membeli atau menjual saham dari emiten yang dimaksud, atau tidak bertransaksi efek dari efek yang dikeluarkan oleh emiten itu. ${ }^{17}$

Dengan misappropriation theory, maka pemerataan informasi di lantai bursa akan lebih terjamin, karena yang menjadi faktor utama dari teori tersebut apakah ada suatu informasi yang disalahgunakan dalam transaksi efek untuk mendapat keuntungan. Penyalahgunaan informasi itu berarti bahwa informasi yang seharusnya diumumkan kepada masyarakat, namun sudah digunakan demi kepentingan sendiri atau malah dibocorkan kepada pihak-pihak tertentu dengan tujuan untuk mendapatkan keuntungan.

Penegakan hukum insider trading mencakup tiga hal, yaitu penegakan secara administratif, perdata, dan pidana. Pada dasarnya UUPM telah meletakkan landasan bagi penegakan hukum sebagai bentuk perlindungan untuk setiap pelanggaran terhadap kegiatan pasar modal, yakni adanya sanksi administratif (Pasal 102 UUPM), sanksi pidana (Pasal 103-110 UUPM), tuntutan ganti kerugian secara perdata (Pasal 111 UUPM).

Larangan perdagangan oleh orang dalam, pada dasarnya adalah agar informasi yang keluar dari perusahaan dapat sampai kepada semua orang (pemodal) secara merata terlebih dahulu sehingga tidak ada satu pihak pun yang diuntungkan, dengan mengingat bahwa informasi di bursa merupakan komoditi penting yang membuat orang memutuskan melakukan atau tidak melakukan investasi. Dengan demikian tidak seorang pun akan diuntungkan terutama apabila yang bersangkutan mempunyai akses terhadap manajemen perusahaan. ${ }^{18}$

Dalam UUPM disebutkan bahwa insider trading sebagaimana diketahui disamping dituntut secara perdata atau sanksi atas perbuatan melawan hukum,

17 Tanaya Velliana, 'Penerapan Misappropriation Theory Dalam Pengaturan Insider Trading Di Indonesia, 2015'<http://e-jurnal.peraturan.go.id/index.php/jli/article/view/372/254> accessed 26 March 2020.

18 Hamud M Balfas, ‘Tindak Pidana Pasar Modal Dan Pengawasan Perdagangan Di Bursa' [1998] Jurnal Hukum dan Pembangunan. [57]. 
juga dapat dituntut secara pidana, namun OJK cenderung ke arah ganti rugi atau denda/sanksi administratif belaka, padahal diketahui insider trading pengaruhnya sangat besar baik kepada investor maupun terhadap pengembangan pasar modal secara keseluruhan. Oleh sebab itu alangkah baiknya jika regulator dapat menyesuaikan dengan keadaan dan kondisi yang berkembang dalam penegakan hukum pasar modal.

Terdapat tiga hal penting yang akan dicapai jika penegakan hukum terhadap kasus insider trading dilaksanakan, yaitu: ${ }^{19}$

1. Regulasi yang efektif dibidang hukum khususnya penegakan hukum secara umum akan menghasilkan pengembangan pasar modal ke arah yang lebih baik sekaligus perlindungan bagi investor.

2. Regulasi yang efektif akan membentuk siklus keterkaitan positif antara investor dan perusahaan publik di mana dengan tingkat resiko yang rendah akan dicapai biaya operasional yang rendah pada akhirnya akan menarik perusahaan-perusahaan untuk menjadi perusahaan publik yang terdaftar di pasar modal.

3. Para regulator dan badan yang menangani penegakan hukum di pasar modal wajib mampu untuk mendeteksi dan mencegah tindakana-tindakan yang dapat merugikan investor. Jika investor kehilangan kepercayaannya maka pasar modal akan masuk pada siklus di mana nilai saham akan jatuh, perusahaan-perusahaan publik yang masuk dalam kategori baik, akan keluar dari pasar modal pada akhirnya aktivitas pasar modal secara keseluruhan akan terhenti.

\section{Kesimpulan}

Pengaturan tentang tindak pidana insider trading (perdagangan orang dalam) dalam Undang-Undang Nomor 8 Tahun 1995 tentang Pasar Modal seharusnya telah memberikan landasan hukum yang setidaknya memberikan ruang gerak

19 Mohammad Nasir, 'Kajian Hukum Atas Insider Trading Di Pasar Modal' <www.lipi. go.id> accessed 26 March 2020. 
yang lebih luas danjelas bagi penegak hukum ataupun stakeholder untuk melakukan langkah preventif sekaligus penindakan kepada para pelanggarnya, hal tersebut dapat tercermin dari pengklasifikasian perbuatan pidana oleh setiap orang yang melakukan insider trading di dalam pasar modal yang tercantum dalam Pasal 95, Pasal 96, Pasal 97, Pasal 98 dan Pasal 104.

Proses penegakan hukum kepada para pelanggar insider trading di Indonesia dianggap masih sangat lemah jika ditinjau pada proses penegakan hukum kasus PT. Bank Danamon Tbk yang pernah ditangani oleh OJK sebagai penanggungjawab dari badan pengawas Pasar Modal di Indonesia yang justru terkesan melepaskan kasus tersebut. Ancaman pidana pada Pasal 103 UUPM yakni pidana penjara maksimal 10 (sepuluh) tahun dan denda paling banyak Rp. 15.000.000.000,00 (lima belas miliar rupiah) tidak diterapkan dalam kasus tersebut. Padahal jika melihat secara keseluruhan dari rangkaian tindakan yang telah dilakukan, penerapan sanksi yang seharusnya diberikan akan jauh lebih berat mengingat kasus ini telah terbukti sebelumnya di dalam Monetary Authority of Singapore. Diharapkan dengan wewenang penyidikan yang lebih luas dengan adanya UU Nomor 21 Tahun 2011 tentang Otoritas Jasa Keuangan dapat menyelesaikan dugaan kasus Insider Trading hingga ke Pengadilan dan tidak sebatas hanya pemberian sanksi administratif kepada para pelaku. Wewenang pengaturan dan pengawasan yang dilakukan OJK diharapkan dapat membuat lembaga di sektor Pasar Modal lebih efisien, sehat dan transparan sehingga masyarakat tidak akan takut lagi berinvestasi di sektor-sektor keuangan lainnya termasuk di sektor Pasar Modal.

\section{Daftar Bacaan}

\section{Buku}

Martalena, Pengantar Pasar Modal. (Penerbit ANDI 2011).

Munir Fuady, Pasar Modal Modern (Tinjauan Hukum) (Citra Aditya Bakti 1996).

Peter Mahmud Marzuki, Penelitian Hukum (Pranada Media Group 2011). 


\section{Jurnal}

Ade Hendra Jaya dan I Nyoman Gatrawan, 'Akibat Hukum Adanya Misleading Information Pada Prospektus Ditinjau Dari Hukum Pasar Modal' (2013) Jurnal Kertha Semaya 1.

Addinul Haq Yaqub, Dhanitya Putra Prawira, Muh. Arief Syahroni, 'The Antinomy of Fictive State Administrative Decision in Indonesian Statute' (2019) Jurnal Jurisprudentie 6 .

Hamud M Balfas, 'Tindak Pidana Pasar Modal dan Pengawasan Perdagangan di Bursa' (1998) Jurnal Hukum dan Pembangunan Edisi Januari-Juni.

Ida Ayu Nyoman Mahayani Dewi dan I Wayan Suarbha, 'Penanggulangan Perdagangan Orang Dalam (Insider Trading) di Bidang Pasar Modal Ditinjau Dari Perspektif Hukum Pidana' (2014) Jurnal Kertha Wicara 3.

I Kadek Andi Wijaya dan Ni Nyoman Sukeni, 'Tanggung Jawab Emiten dan Profesi Penunjang Atas Adanya Prospektus Yang Tidak Benar Dalam Kegiatan Di Pasar Modal' (2013) Jurnal Kertha Semaya 1.

Inocencio Arya Wahyudi Karditha, I Ketut Westra, Ni Putu Purwanti, 'Tanggung Jawab Akuntan Publik Dalam Pembuatan Prospektus Pada Kegiatan di Pasar Modal' (2013) Jurnal Kertha Semaya 1.

Kadek Endra Bayu Sudiartha dan Made Subawa, 'Perlindungan Hukum Terhadap Investor Untuk Menghindari Kerugian Akibat Praktek Manipulasi Pasar Dalam Pasar Modal' (2013) Jurnal Kertha Semaya 1.

Lana Almira Luthfiana Istiqlal dan Dian Purnama Anugerah, 'Perlindungan Hukum Bagi Konsumen Pengguna Kartu Debit Terkait Pembebanan Biaya Tambahan Pada Mesin EDC (Electronic Data Captured)' (2020) Media Iuris 3.

Mohammad Solehuddin Attijani, 'Penyelenggara Dana Perlindungan Pemodal Bagi Investor Dalam Transaksi Saham Pada Pasar Modal' (2019) Media Iuris 2.

Moh. Heriyanto, Wahyu Hidayatullah, Mulyadi, 'Konsep Kriminalisasi Penegakan Hukum Terhadap Pembeli Aktif Ilegal Obat Keras Daftar "G" Jenis Trihexyphenidil' (2020) Media Iuris 3.

Pande Putu Mega Rahma Wulandari dan Gde Made Swardhana, 'Tanggung Jawab Terhadap Pelanggaran Prinsip Keterbukaan Dalam Pasar Modal Terkait Perdagangan Saham' (2017) Jurnal Kertha Semaya 5.

Putu Wahyu Ning Egarini dan I Made Sarjana, 'Problematika Memorandum of 
Understanding' (2020) Jurnal Kertha Semaya 8.

\section{Laman}

Mohammad Nasir, Kajian Hukum Atas Insider Trading di Pasar Modal, www.lipi. go.id diunduh 26 Maret 2020.

Tanaya Velliana, 'Penerapan Misappropriation Theory Dalam Pengaturan Insider Trading di Indonesia' (2015). <http://ejurnal.peraturan.go.id/index.php/ jli/article/view/372/254>. di akses pada tanggal 26 Maret 2020.

How to cite: Ardian Junaedi, 'Tindak Pidana Insider Trading Dalam Praktik Pasar Modal Indonesia' (2020) Vol. 3 No. 3 Media Iuris. 